University of Nebraska - Lincoln

DigitalCommons@University of Nebraska - Lincoln

Agronomy \& Horticulture -- Faculty Publications

Agronomy and Horticulture Department

2007

\title{
Map Location of the Rpp1 Locus That Confers Resistance to Soybean Rust in Soybean
}

\author{
D. L. Hyten
}

Soybean Genomics and Improvement Laboratory, USDA Agricultural Research Service, Beltsville, Maryland, david.hyten@unl.edu

G. L. Hartman

University of Illinois

R. L. Nelson

University of Illinois, rInelson@illinois.edu

R. D. Frederick

USDA-ARS, Foreign Disease-Weed Science Research Unit, reid.frederick@usda.gov

V. C. Concibido

Monsanto Co., St. Louis, MO 63167

See next page for additional authors

Follow this and additional works at: https://digitalcommons.unl.edu/agronomyfacpub

Part of the Agricultural Science Commons, Agriculture Commons, Agronomy and Crop Sciences Commons, Botany Commons, Horticulture Commons, Other Plant Sciences Commons, and the Plant Biology Commons

Hyten, D. L.; Hartman, G. L.; Nelson, R. L.; Frederick, R. D.; Concibido, V. C.; Narvel, J. M.; and Cregan, P. B., "Map Location of the Rpp1 Locus That Confers Resistance to Soybean Rust in Soybean" (2007).

Agronomy \& Horticulture -- Faculty Publications. 784.

https://digitalcommons.unl.edu/agronomyfacpub/784

This Article is brought to you for free and open access by the Agronomy and Horticulture Department at DigitalCommons@University of Nebraska - Lincoln. It has been accepted for inclusion in Agronomy \& Horticulture -Faculty Publications by an authorized administrator of DigitalCommons@University of Nebraska - Lincoln. 


\section{Authors}

D. L. Hyten, G. L. Hartman, R. L. Nelson, R. D. Frederick, V. C. Concibido, J. M. Narvel, and P. B. Cregan 


\title{
Map Location of the Rpp1 Locus That Confers Resistance to Soybean Rust in Soybean
}

\author{
D. L. Hyten, G. L. Hartman, R. L. Nelson, R. D. Frederick, \\ V. C. Concibido, J. M. Narvel, and P. B. Cregan^
}

\section{ABSTRACT}

Soybean rust (SBR), caused by Phakopsora pachyrhizi, was first discovered in North America in 2004 and has the potential to become a major soybean [Glycine max (L.) Merr.] disease in the USA. Currently, four SBR resistance genes have been identified but not mapped on the soybean genetic linkage map. One of these resistance genes is the Rpp1 gene, which is present in the soybean accession PI 200492. The availability of molecular markers associated with Rpp1 will permit marker-assisted selection and expedite the incorporation of this gene into U.S. cultivars. We compared simple sequence repeat (SSR) markers between 'Williams 82 ' and the $\mathrm{BC}_{5}$ Williams 82 isoline L85-2378, which contains the Rpp1 resistance allele from the soybean accession $\mathrm{PI} 200492$, for candidate regions that might contain Rpp1. One candidate region was found with the SSR marker BARC_Sct_187 on linkage group $\mathrm{G}$. A population of $\mathrm{BC}_{6} \mathrm{~F}_{2: 3}$ lines segregating for the Rpp1 resistance locus was genotyped in this region on linkage group $\mathrm{G}$ followed by inoculation with the $P$. pachyrhizi isolate India 73-1 in the USDA-ARS Biosafety Level 3 Plant Pathogen Containment Facility at Ft. Detrick, MD. The Rpp1 gene was mapped between SSR markers BARC_Sct_187 and BARC_Sat_064 on linkage group $\mathrm{G}$.
D.L. Hyten and P.B. Cregan, USDA-ARS, Soybean Genomics and Improvement Lab., Beltsville, MD 20705; R.L. Nelson and G.L. Hartman, USDA-ARS, Dep. of Crop Sciences, Univ. of Illinois, Urbana, IL 61801; R.D. Frederick, USDA-ARS, Foreign Disease-Weed Science Research Unit (FDWSRU), Ft. Detrick, MD 21702; V.C. Concibido, Monsanto Co., St. Louis, MO 63167; J.M. Narvel, Monsanto Co., Galena, MD 21635. Received 21 July 2006. *Corresponding author (creganp@ba.ars.usda.gov).

Abbreviations: cM, centimorgan; SBR, soybean rust; SSR, simple sequence repeat.

Soybean rust (SBR), which is caused by the pathogen Phakopsora pachyrhizi Syd., has recently been identified in North America (Schneider et al., 2005). It has the potential for significant yield losses and major economic damage to U.S. soybean [Glycine $\max ($ L.) Merr.] production (Grau et al., 2004). Weather conditions conducive to high soybean yields are also ideal for spread of SBR, which can cause yield losses up to 80\% (Miles et al., 2003). Most cultivars grown in the USA are highly susceptible to SBR, leading to possible epidemics in the future if weather conditions are conducive to disease development (Miles et al., 2006).

Little information is available to soybean breeders on SBR host resistant genes for integration into modern breeding lines. Initial studies have identified four unlinked dominant resistance genes. The soybean accession PI 200492 has been described as having a single dominant gene for resistance to SBR (McLean and Byth, 1980). The locus was later named Rpp1, which confers an immune response (no lesions) when inoculated with certain $P$. pachyrhizi isolates, including the isolate India 73-1 (Hartwig and Bromfield, 1983). The other three resistant genes (Rpp2, $R p p 3$, and $R p p 4)$ confer a resistant

Published in Crop Sci 47:837-840 (2007).

doi: 10.2135/cropsci2006.07.0484

(C) Crop Science Society of America

677 S. Segoe Rd., Madison, WI 53711 USA

All rights reserved. No part of this periodical may be reproduced or transmitted in any form or by any means, electronic or mechanical, including photocopying, recording, or any information storage and retrieval system, without permission in writing from the publisher. Permission for printing and for reprinting the material contained herein has been obtained by the publisher. 
reaction when inoculated with certain $P$. pachyrhizi isolates, which is characterized by dark, reddish-brown lesions with few or no spores (Hartwig, 1986; Hartwig and Bromfield, 1983). The susceptible reaction phenotype to infection by $P$. pachyrhizi is characterized by distinct tan lesions with prolific sporulation (Bromfield and Hartwig, 1980). These resistance genes have been shown to be susceptible to specific isolates of $P$. pachyrhizi, and it is unknown how they will react with current isolates within the USA. Although specific P. pachyrhizi strains are virulent on these single gene resistant sources, it may be beneficial to pyramid these four known resistant genes into modern cultivars to create broad spectrum resistance to SBR in the USA. (Hartman et al., 2005).

One of the difficulties of integrating these resistance genes into modern cultivars is that SBR is still considered an invasive pathogen in most of the USA. Currently, all research in the USA with the foreign isolates of P. pachyrhizi that define the current SBR resistant genes must be done under Biosafety Level 3 (BSL-3) containment. Molecular markers have been successfully applied in crops for identifying the location of disease resistance loci and for marker-assisted selection (Concibido et al., 2004; Orf et al., 2004). Simple sequence repeat (SSR) markers, one common marker used in marker-assisted selection, are polymerase chain reaction (PCR)-based, are often highly polymorphic, and can be assayed on inexpensive gel electrophoresis systems. Soybean currently has an SSR map that contains 1019 SSR markers distributed across 20 linkage groups (Song et al., 2004). These markers can be used to identify the genome location of SBR resistant genes and to help quickly integrate these genes into modern breeding lines through marker-assisted selection. Our objective was to map the Rpp 1 resistance gene to a genetic map location to help facilitate marker-assisted selection.

\section{MATERIALS AND METHODS Plant Material}

A population of $126 \mathrm{BC}_{6} \mathrm{~F}_{2}$ lines segregating for the SBR Rpp 1 resistance allele was used in the study. $\mathrm{L} 85-2378$, the $\mathrm{BC}_{5}$ rust resistant isoline of 'Williams 82' developed with rust resistance (Rpp1) from the donor parent PI 200492, was backcrossed to Williams 82 in the greenhouse in the winter of 2002-2003. L85-2378 was selected using the P. pachyrhizi isolate India 731 during each cycle of backcrossing. The $\mathrm{BC}_{6} \mathrm{~F}_{1}$ plants were grown at Urbana, IL, in 2003, and the $\mathrm{BC}_{6} \mathrm{~F}_{2}$ population was planted in a winter nursery in Puerto Rico in fall 2003. Single $\mathrm{BC}_{6} \mathrm{~F}_{2}$ plants were harvested in spring 2004 to create the $\mathrm{BC}_{6} \mathrm{~F}_{2}$ lines used in this research. Seeds of Williams 82, PI 200492, and L85-2378 used to produce plants for crossing and DNA extraction were obtained from the USDA Soybean Germplasm Collection (USDA-ARS, Univ. of Illinois, Urbana, IL).

\section{Rust Inoculation and Phenotyping}

All SBR phenotyping was performed in the USDA-ARS FDWSRU BSL-3 Plant Pathogen Containment Facility at Ft.
Detrick, MD (Melching et al., 1983). There were two replications of the phenotyping of the Rpp1 population due to initial space limitations in the containment facility for the first replication, which was a pilot study. The first replication consisted of $83 \mathrm{BC}_{6} \mathrm{~F}_{2}$ lines with three $\mathrm{BC}_{6} \mathrm{~F}_{3}$ plants per line. The second replication consisted of additional $\mathrm{BC}_{6} \mathrm{~F}_{3}$ progeny of the same $83 \mathrm{BC}_{6} \mathrm{~F}_{2}$ lines plus $\mathrm{BC}_{6} \mathrm{~F}_{3}$ progeny of 43 additional $\mathrm{BC}_{6} \mathrm{~F}_{2}$ lines. In the second replication, $10 \mathrm{BC}_{6} \mathrm{~F}_{3}$ progeny were grown per $\mathrm{BC}_{6} \mathrm{~F}_{2}$ line. Two seeds were planted in Sunshine $\mathrm{LC}_{1} \mathrm{mix}$ (Sun Grow Horticulture Products, Belleview, WA) per cell in a (27 $\times 52 \mathrm{~cm}$ ) flat that contained $6 \times 12$ cells. Plants were thinned to a single plant per cell $10 \mathrm{~d}$ after planting. To ensure uniformity of inoculation conditions, the flats positioned on the outside edges of the greenhouse had extra border rows of a susceptible soybean cultivar (i.e., Williams 82 or Maverick). Resistant and susceptible checks were planted randomly throughout the flats and included the original donor parent of the Rpp 1 resistance allele, PI 200492, as well as the resistant isoline parent, L852378 , and the susceptible parent, Williams 82 .

Inoculations were done on 15-d-old seedlings in sets of 10 to 22 flats each. Plants were inoculated with the P. pachyrhizi isolate India 73-1, which has been well characterized for eliciting an immune reaction on the accession PI 200492. Inoculum was produced from urediniospores stored in liquid nitrogen that were heat shocked at $40^{\circ} \mathrm{C}$ for $5 \mathrm{~min}$, hydrated overnight in a small plastic weigh boat above water in an enclosed Petri plate. Urediniospores were suspended in distilled water containing $0.01 \%$ Tween-20, mixed, and filtered through a $53-\mathrm{mm}$ nylon screen to remove any debris or clumps of urediniospores. Urediniospores were quantified using a hemocytometer to a final concentration of 20000 per $\mathrm{mL}$, and inoculations were done using $80 \mathrm{~mL}$ per flat, applied with an atomizer at 20 poundforce per square inch. Immediately after inoculation, plants were placed in a dew chamber at $20^{\circ}$ to $22^{\circ} \mathrm{C}$ overnight, then placed on a greenhouse bench where temperatures were maintained between $20^{\circ}$ and $25^{\circ} \mathrm{C}$. Supplemental lighting was provided by $1000-\mathrm{W}$ Metalarc lights (Sylvania, Daners, MA) spaced $0.6 \mathrm{~m}$ apart and $1.2 \mathrm{~m}$ above the bench. Seventeen days after inoculation, the unifoliolate and trifoliolate leaves of each plant were evaluated for reaction to soybean rust. Resistant reactions (immune) were recorded when no lesions were observed on the unifoliolate or trifoliolate leaves (Hartwig and Bromfield, 1983). A susceptible reaction (tan) was recorded when distinct tan lesions with prolific sporulation was observed on the unifoliolate or trifoliolate leaves (Bromfield and Hartwig, 1980).

\section{SSR Screening for Candidate Regions}

Ten seeds each of PI 200492, L85-2378, and Williams 82 were grown, and leaf tissue from the 10 plants was bulked and used for DNA extraction using the modified procedure outlined by Dellaporta et al. (1983). A total of 400 SSR markers from the integrated molecular genetic linkage map of soybean (Song et al., 2004) spaced at an average of 5-centimorgan (cM) throughout the 20 chromosomes was tested on PI 200492, L85-2378, and Williams 82 . Simple sequence repeat genotyping and allele size determination were performed as described by Cregan et al. (1999). Polymorphic markers between Williams 82 and L852378 where L85-2378 shared an allele with PI 200492 were 
considered candidate markers for screening the L85-2378 $\times$ Williams 82 population segregating for $R p p 1$ resistance.

\section{Population SSR Screening}

Before inoculation with SBR, a single leaflet was collected from the first trifoliolate or, in some instances, the whole second trifoliolate from each $\mathrm{BC}_{6} \mathrm{~F}_{3}$ plant in the two replication population screening already described. Leaf tissue was immediately frozen on dry ice. DNA was isolated from the leaf tissue using the Sigma REDExtractN-Amp Plant PCR Kit (Sigma-Aldrich, St. Louis, MO), following the manufacturer's instructions. Simple sequence repeat markers in the candidate intervals were used to genotype one $\mathrm{BC}_{6} \mathrm{~F}_{3}$ plant from the first $10 R p p 1 \mathrm{BC}_{6} \mathrm{~F}_{2}$ lines to confirm the SSR locus was segregating in the population. Once a marker was determined to be segregating, it was used to screen between 6 and $13 \mathrm{BC}_{6} \mathrm{~F}_{3}$ plants from each of the $126 \mathrm{BC}_{6} \mathrm{~F}_{2}$ lines. Simple sequence repeat genotyping was performed as described by Cregan et al. (1999), and SSR allele size differences were determined as described by Wang et al. (2003) or with a $2 \%$ agarose gel. The genotype of each $\mathrm{F}_{2}$ plant was inferred from the genotypes of its $\mathrm{F}_{2: 3}$ progeny. Map Manager QTX v. b20 (Manly et al., 2001) was used with Kosambi's mapping function to estimate genetic distances between SSR markers and Rpp1 in the $126 \mathrm{BC}_{6} \mathrm{~F}_{2}$ lines of Williams $82 \times$ PI 200492 .

\section{RESULTS AND DISCUSSION}

The initial comparison of L85-2378, PI 200492, and Williams 82 identified one genomic region where L85-2378 shared an allele with PI 200492 and was polymorphic with Williams 82. This region was identified with the SSR marker BARC_Sct_ 187 on linkage group G. Since L85-2378 resulted from five backcrosses of PI 200492 to Williams 82, the genome of L852378 should be on average $98.4 \%$ identical to Williams 82 . This would make any remaining donor segments candidate regions that may contain the $R p p 1$ gene. The candidate region was first tested on 10 plants from the population to confirm it was segregating in the population before being tested on all 126 families. The initial test confirmed that Sct_187 did segregate in the population.

The number of resistant-to-susceptible lines in the population fit the expected 3:1 ratio (Table 1). A 1:2:1 segregation ratio of the single dominant resistant gene (Rpp1) was confirmed when the reactions of individual plants from the $\mathrm{BC}_{6} \mathrm{~F}_{2: 3}$ lines were analyzed to permit the inference of $\mathrm{BC}_{6} \mathrm{~F}_{2}$ genotype. The SSR marker Sct_187 also fit a 1:2:1 ratio in the $\mathrm{BC}_{6} \mathrm{~F}_{2}$ pop-
Table 1. Inheritance of soybean rust resistance and the SSR marker BARC_Sct_187 and the genetic linkage between the two in a population of BC6F2 lines from Williams $82 \times$ PI 200492.

\begin{tabular}{llllll}
\hline \multicolumn{1}{c}{ Locus } & $\begin{array}{c}\text { Generation } \\
\text { analyzed }\end{array}$ & $\begin{array}{c}\text { Expected } \\
\text { ratio }\end{array}$ & $\begin{array}{c}\text { Observed } \\
\text { ratio }\end{array}$ & $\begin{array}{c}\text { Chi- } \\
\text { square }\end{array}$ & Probability \\
\hline Rpp1 & $\mathrm{BC}_{6} \mathrm{~F}_{2}$ & $3: 1$ & $94: 32$ & 0.01 & 0.92 \\
Rpp1 & $\mathrm{BC}_{6} \mathrm{~F}_{2: 3}$ & $1: 2: 1$ & $32: 62: 32$ & 0.03 & 0.99 \\
Sct_187 & $\mathrm{BC}_{6} \mathrm{~F}_{2}$ & $1: 2: 1$ & $30: 65: 31$ & 0.14 & 0.93 \\
Rpp1/Sct_187 & $\mathrm{BC}_{6} \mathrm{~F}_{2}$ & $3: 6: 3: 1: 2: 1^{\dagger}$ & $30: 64: 0: 0: 1: 31$ & 120.9 & $<0.0001$ \\
\hline
\end{tabular}

'Expected ratio of independent segregation of one dominant and one codominant locus R_/AA: R_/Aa:R_/aa:rr/AA:rr/Aa:rr/aa (R_ immune, rr tan lesions, AA homozygous for the PI 200492 allele, aa homozygous for the Williams 82 BARC_Sct_187 allele, Aa heterozygous). 
Van Ooijen and Voorrips, 2001) of five mapping populations. To investigate which map order is correct, we examined the genotype data in the individual populations used to create the consensus map. One of the populations used by Song et al. (2004) was the Minsoy $\times$ Archer recombinant inbred line population and was the only population in which all three of the markers Sct_187, Sat_064, and Sat_372 were analyzed. When the order of these markers was determined in the Minsoy $\times$ Archer population alone, the order agrees with that determined in the present study (Fig. 1). The apparent inversion in the consensus map is most likely caused by the JoinMap analysis of the multiple populations.

Sct_187 is in a genomic region that has had association with other disease resistance loci. Concibido et al. (1997) found a minor soybean cyst nematode resistance gene linked to A378_1, which is 2 cM away from Sct_187. The Rps4, Rps5, and Rps6 resistance genes to Phytophthora root rot (caused by Phytophthora megasperma Drechs. F. sp. glycinea Kuan and Ervin) have been mapped to this same region on LG G (Demirbas et al., 2001; Diers et al., 1992).

The tight linkage of the flanking markers Sct_187 and Sat_064 to Rpp1 makes these SSR markers useful for marker-assisted selection. Sct_187 and Sat_064 have gene diversity estimates of 0.46 and 0.84 , respectively (Cregan et al., 1999), which indicates these markers will be polymorphic in a wide range of crosses. In addition to the flanking markers, the other two SSR markers in this region, Sat_372 and Sat_117 (Song et al., 2004), may be useful for marker-assisted selection depending on the parents of the germplasm being analyzed. Since there are only a few SSR markers available, the development of additional SSR and single nucleotide polymorphism markers will help breeders to integrate the Rpp1 resistance allele into modern cultivars and facilitate the fine mapping of the gene.

\section{Acknowledgments}

We wish to thank Edward Fickus and Jason Kenworthy for their technical help in the genotyping of the population and Liesa Cerny for the initial SSR screening work to identify the candidate gene locations. This work supports the goals of the USDA National Strategic Plan for the Coordination and Integration of Soybean Rust Research (http://www.apsnet.org/online/sbr/pdf/USDASo ybeanRustStratPlanv1.3.pdf) and was partially funded by United Soybean Board Project \# 6235 titled "Identification and Utilization of Resistance to Soybean Rust” and the Monsanto Company.

\section{References}

Bromfield, K.R., and E.E. Hartwig. 1980. Resistance to soybean rust and mode of inheritance. Crop Sci. 20:254-255.

Concibido, V.C., B.W. Diers, and P.R. Arelli. 2004. A decade of QTL mapping for cyst nematode resistance in soybean. Crop Sci. 44:1121-1131.

Concibido, V.C., D.A. Lange, R.L. Denny, J.H. Orf, and N.D. Young. 1997. Genome mapping of soybean cyst nematode resistance genes in 'Peking', PI 90763 and PI 88788 using DNA markers. Crop Sci. 37:258-264.
Cregan, P.B., T. Jarvik, A.L. Bush, R.C. Shoemaker, K.G. Lark, A.L. Kahler, N. Kaya, T.T. VanToai, D.G. Lohnes, and J. Chung. 1999. An integrated genetic linkage map of the soybean genome. Crop Sci. 39:1464-1490.

Dellaporta, S.L., J. Wood, and J.B. Hicks. 1983. A plant DNA minipreparation: Version II. Plant Mol. Biol. Rep. 1:19-21.

Demirbas, A., B.G. Rector, D.G. Lohnes, R.J. Fioritto, G.L. Graef, P.B. Cregan, R.C. Shoemaker, and J.E. Specht. 2001. Simple sequence repeat markers linked to the soybean Rps genes for phytophthora resistance. Crop Sci. 41:1220-1227.

Diers, B.W., L. Mansur, J. Imsande, and R.C. Shoemaker. 1992. Mapping phytophthora resistance loci in soybean with resistance fragment length polymorphism markers. Crop Sci. 32:377-383.

Grau, C.R., A.E. Dorrance, J. Bond, and J.S. Russin. 2004. Fungal Diseases. p. 679-763. In H. R. Boerma, and J. E. Specht (ed.) Soybeans: Improvement, production, and uses. 3rd ed. Agron. Monogr. 16. ASA, CSSA, and SSSA, Madison, WI.

Hartman, G.L., M.R. Miles, and R.D. Frederick. 2005. Breeding for resistance to soybean rust. Plant Dis. 89:664-666.

Hartwig, E.E. 1986. Identification of a fourth major gene conferring resistance to soybean rust. Crop Sci. 26:1135-1136.

Hartwig, E.E., and K.R. Bromfield. 1983. Relationships among three genes conferring specific resistance to rust in soybeans. Crop Sci. 23:237-239.

Manly, K.F., R.H. Cudmore, Jr., and J.M. Meer. 2001. Map Manager QTX, cross-platform software for genetic mapping. Mamm. Genome 12:930-932.

McLean, R.J., and D.E. Byth. 1980. Inheritance of resistance to rust (Phakopsora pachyrhizi) in soybeans. Aust. J. Agric. Res. 31:951-956.

Melching, J.S., K.R. Bromfield, and C.H. Kingsolver. 1983. The plant pathogen containment facility at Frederick, Maryland. Plant Dis. 67:717-722.

Miles, M.R., R.D. Frederick, and G.L. Hartman. 2003. Soybean rust: Is the U.S. crop at risk? http://www.apsnet.org/online/ feature/rust/(posted June 2003; verified 3 Jan. 2007). American Phytopathological Society.

Miles, M.R., R.D. Frederick, and G.L. Hartman. 2006. Evaluation of soybean germplasm for resistance to Phakopsora pachyrhizi http://dx.doi.org/10.1094/PHP-2006-0104-01-RS (posted Jan. 2006; verified 3 Jan. 2007). Plant Health Progress.

Orf, J.H., B.W. Diers, and H.R. Boerma. 2004. Genetic improvement: Conventional and molecular-based strategies. $\mathrm{p}$ 417-450. In H. R. Boerma and J. E. Specht (ed.) Soybeans: Improvement, production, and uses. 3rd ed. Agron. Monogr. 16. ASA, CSSA, and SSSA, Madison, WI.

Schneider, R.W., C.A. Hollier, H.K. Whitam, M.E. Palm, J.M. McKemy, J.R. Hernandez, L. Levy, and R. DeVries-Paterson. 2005. First report of soybean rust caused by Phakopsora pachyrhizi in the continental United States. Plant Dis. 89:774.

Song, Q.J., L.F. Marek, R.C. Shoemaker, K.G. Lark, V.C. Concibido, X. Delannay, J.E. Specht, and P.B. Cregan. 2004. A new integrated genetic linkage map of the soybean. Theor. Appl. Genet. 109:122-128.

Van Ooijen, J.W., and R.E. Voorrips. 2001. JoinMap 3.0 software. Plant Research International, Wageningen, the Netherlands.

Wang, D., J. Shi, S.R. Carlson, P.B. Cregan, R.W. Ward, and B.W. Diers. 2003. A low-cost, high-throughput polyacrylamide gel electrophoresis system for genotyping with microsatellite DNA markers. Crop Sci. 43:1828-1832. 